\title{
Numerical Analysis and Application on the Parameters Optimization of Open-pit Deep-Hole Bench Loose Blasting
}

\author{
Guang-tao $\mathrm{Li}^{1,2}$, Deng-pan Qiao ${ }^{1}$,Hong-sheng $\mathrm{Sun}^{2}$ and Li-hua $\mathrm{He}^{3}$ \\ ${ }^{1}$ Kunming university of science and technology, Kunming 650093, China \\ ${ }^{2}$ Dahongshan copper mine of Yuximingingco.LTD, Yuxi 653100,China \\ ${ }^{3}$ Faculty of Mining Industry, Kunming Metallurgy College, Kunming650033, \\ China \\ jiang2012jiang2012@qq.com
}

\begin{abstract}
In order to improve the production efficiency of mine and ensure production safety and aiming at the unsatisfying blasting effects and uneven rock fragments existing in the exploitation blasting and construction process in Manjiazhai stope of Hualian Zinc and Indium Stock company, this paper analyzes and optimizes loosening blasting parameters of Open-pit deep-hole benches based on the blasting mechanism and engineering practical experience of wide hole distance and small resistance lines. Utilizing the numerical simulation of finite element software with ANSYS/LS-DYNA various schemes, analysis validations on the blasting stress field under different parameters are conducted. The simulation results show that: When the holes and rows spacing are 15×9, 16×9, $17 \times 8$, the effective stress of discrete cells between blast holes is bigger than the dynamic tensile strength that rocks can be broken. The site experimental investigation is conducted. The blasting effect assessment shows that the control rates of the big size rocks when the holes and rows spacing are $16 \times 9$ is $1.904 \%$ lower than those when those are $15 \times 9$, and $1.079 \%$ lower than those are $17 \times 8$. And the shovel mucking efficiency and composite economic results are better than that of the other two groups of parameters and confirmed the best blasting parameter design.
\end{abstract}

Keywords: deep-hole blasting; loose blasting; parameters optimization; numerical simulation; blasting experiment

\section{Introduction}

Open-pit deep-hole bench blasting is the main method [1] for stripping and exploiting Open-pit mines. It has been widely used in large and middle Open-pit mines and excavations of large scale projects [2] because of its easy approach to construction comprehensive mechanization with large blasted volume which is in favor of speeding up construction and improves project quality and reducing project cost.

The blasting quality has direct influence on smoothness of stopes, stowage efficiency, stability of side slope, production safety and economic benefit [3]. There are many problems in the blasting process, such as frequent adjusted or unreasonable parameters which cause unsatisfying actual blasting effect, exploiting height unqualified with the requirements of design and production, uneven broken lumpiness and ore dissipation and dilution. These problems have serious influence on normal safety production and economic benefit. Therefore, it's significant to optimize and research on the loosening blasting parameters of Open-pit deep-hole benches [4].

At present, the most common methods for blasting parameter optimization are field test, BP neural network, genetic algorithm and numerical simulation [5-6].The field test and the analysis on field blasting effects in this paper is based on the blasting mechanisms 
of wide hole distance, small resistance lines proposed by $\mathrm{U} \bullet$ Lange Firth and others [7-8], combined the existing blasting parameter at Manjiazhai stope of Hualian Zinc and Indium Stock company, selected different blasting parameters through theoretical calculation and project practical experience, analyzing numerical simulation and verifying the rationality of blasting parameters with finite element software ANSYS/LS-DYNA.

\section{Blasting Parameters Conformation}

\subsection{Project Overview}

The ore-rock in Manjiazhai stope is mainly schist, skarn and marbles. In which schist is the main surrounding rocks of the ore body with serious developed joints and bad integrity. Skarn is in partial ore body with comparatively developed fracture and bad integrity. Marbles are secondary surrounding rocks of the ore body, which is influenced but its structure, with developed joints and fracture, stratiform, stratiform-like or lentoid stratum. The physical and mechanics parameters of rocks are as showed in Table 1.

Table 1. The Physical and Mechanics Parameters of Rock

\begin{tabular}{|c|c|c|c|}
\hline Rock & $\begin{array}{c}\text { Compressive } \\
\text { Strength/MPa }\end{array}$ & Density/kg. $\mathbf{m}^{-3}$ & $\begin{array}{c}\text { The Strength } \\
\text { Coefficient of Rock } / \boldsymbol{f}\end{array}$ \\
\hline schist & 23.5 & $2300 \sim 2600$ & $4 \sim 6$ \\
\hline skarn & 59.6 & 3000 & $8 \sim 10$ \\
\hline marbles & 40.1 & 2700 & $10 \sim 12$ \\
\hline
\end{tabular}

In the long-term running of mines, $15 \mathrm{~m}$ bench has been formed in Manjiazhai stope. The existing drilling diameter is mainly $250 \mathrm{~mm}$ used in vertical drilling holes. Explosive is RJ1\# high-yield rock emulsion explosive. The specifications of cartridges: $\varphi 120 \mathrm{~mm}-$ $6.0 \mathrm{~kg}$; Use millisecond nonel detonator though hole-by-hole initiation. The blasting construction is loosening blasting of deep-hole bench.

\subsection{Confirmation of Density Coefficient of Hole Pattern}

Reasonable density coefficient of whole pattern may ensure the good blasting effect of rock blasting. Professor Zong Qi in Huainan University of Science and Technology had Single-hole funnel test and two-hole blasting test on the density coefficient of loosening blasting and got the best density coefficient scope of loosening blasting is 1.5 2.0[9] According to the requirements of Manjiazhai stope of Hualian Zinc and Indium Stock company on refining mining and the nature of rocks, the density coefficient of holes pattern shall be between 1.5 2.5.

\subsection{Bottom Burden Confirmation}

In the element which influences the blasting effects of bench, bottom burden is a significant parameter. Bottom burden is relevant to aperture, bench height, lithology and other elements. According to blasting practical experience, bottom burden is designed according to the aperture and bench height as showed in formula (1), (2):

(1)According to the bench height:

$$
W_{d}=(0.6 \sim 0.9) H
$$

which, $W_{\mathrm{d}}-$ Bottom burden, m;

$H$-bench height, $\mathrm{m}$.

(2) According to the aperture: 


$$
W_{d}=K \cdot d
$$

Which, $\mathrm{W}_{\mathrm{d}}$ - Bottom burden, $\mathrm{m}$;

$d$ - the aperture, $\mathrm{mm}$;

$K$ - coefficient.

According to blasting experience formula and the actual situation of stope, the bottom burden in this design is.

\subsection{Hole and Row Spacing Confirmation}

According to single-hole burden area confirm the hole spacing and row spacing as showed in formula (3):

$s=a \cdot b$

According to the elation of the density coefficient $m$ of blast holes confirm the hole spacing and row spacing as showed in formula (4):

$m=\frac{a}{b}$

6 groups of parameters are primarily selected according to the design thought of wide hole distance and small resistance lines widely used in Open-pit mines in home and abroad and the density coefficient of blast holes confirmed in section 1.2, combining the actual situation of Manjiazhai stope and the site test construction. The combinations of holes and rows spacing are as following Table 2.

Table 2. The Combinations of Holes and Rows Spacing

\begin{tabular}{|c|c|c|c|c|}
\hline Number & $\begin{array}{c}\text { Hole } \\
\text { spacing a/m }\end{array}$ & $\begin{array}{c}\text { Row spacing } \\
\mathbf{b} / \mathbf{m}\end{array}$ & $\begin{array}{c}\text { Single-hole } \\
\text { burden area s/m }\end{array}$ & $\begin{array}{c}\text { The elation of the } \\
\text { density coefficient } \mathbf{m}\end{array}$ \\
\hline $\mathbf{1}$ & 15 & 10 & 150 & 1.50 \\
\hline $\mathbf{2}$ & 15 & 9 & 135 & 1.67 \\
\hline $\mathbf{3}$ & 16 & 9 & 144 & 1.78 \\
\hline $\mathbf{4}$ & 17 & 8 & 136 & 2.13 \\
\hline $\mathbf{5}$ & 18 & 8 & 144 & 2.25 \\
\hline $\mathbf{6}$ & 19 & 7 & 133 & 2.71 \\
\hline
\end{tabular}

\subsection{Other Blasting Parameters Conformation}

The short-interval delay initiation is used in bench explosive exploitation on mines. It requires that the delayed time interval shall meet with the time needed in the free face made by back row blast holes explosion after the explosion of front row blast holes ${ }^{[10-}$ ${ }^{11]}$. The delayed time between holes is confirmed as $25 \mathrm{~ms}$ according to the nature of the ore-rock in Manjiazhai stope and existing nonel detonator on the mine; The delayed time between rows is $110 \mathrm{~ms}$.

\section{Numerical Simulation Analysis}

In order to shorten the time of site production test, and reduce the influences on the normal production of mines, this paper built a Open-pit bench blasting simulation with ANSYS/LS-DYNA software of finite element analysis, conducted numerical simulation 
on blasting hole pattern parameters, forecast the blasting fracture effects. The simulated blasting parameter is as showed in Table 3. ALE algorithm is adopted in the numerical calculation. The grid partitioning is gradient parted by mapped partitioning. Coupling analysis between rock mass and explosive is conducted [6].

Table 3. The Simulated Blasting Parameters

\begin{tabular}{|c|c|c|c|c|c|}
\hline \multirow{2}{*}{$\begin{array}{c}\text { Model } \\
\text { number }\end{array}$} & \multirow{2}{*}{ Hole depth /m } & \multicolumn{2}{|c|}{ Delayed time/ms } & \multirow{2}{*}{$\begin{array}{c}\text { Hole } \\
\text { spacing/m }\end{array}$} & \multirow{2}{*}{$\begin{array}{c}\text { Row } \\
\text { spacing/m }\end{array}$} \\
\hline & & holes & rows & & \\
\hline $1-1$ & \multirow{6}{*}{17.5} & \multirow{6}{*}{25} & \multirow{6}{*}{110} & 15 & 10 \\
\hline $1-2$ & & & & 15 & 9 \\
\hline $1-3$ & & & & 16 & 9 \\
\hline $1-4$ & & & & 17 & 8 \\
\hline $1-5$ & & & & 18 & 8 \\
\hline $1-6$ & & & & 19 & 7 \\
\hline
\end{tabular}

\subsection{Calculation Model}

5 blast holes are set in calculation model. The blast holes are layout as diamond, the sizes of substances in each part of the holes are: $15 \mathrm{~m}$ bench, $17.5 \mathrm{~m}$ hole depth, $6 \mathrm{~m}$ stemming height, $11.5 \mathrm{~m}$ charging height and $1.5 \mathrm{~m}$ preserved rock bottom. SOLID164 entity unit with $3 \mathrm{D}$ explicit structure is selected. The surfaces and front slope of the bench is free faces, the other faces are reflection-free boundary. Down hole detonating and holeby-hole initiating is calculated. Model dimensions, shapes and the layout of blast hole is layout as Table 4, and Figure 1.

Table 4. Calculation Model Dimensions

\begin{tabular}{|c|c|c|c|c|c|c|c|c|}
\hline $\begin{array}{c}\text { bench } \\
\text { height/m }\end{array}$ & $\begin{array}{c}\text { Poreradius } \\
\text { /mm }\end{array}$ & $\mathbf{h} / \mathbf{m}$ & $\mathbf{L} / \mathbf{m}$ & $\mathbf{L} \mathbf{1} / \mathbf{m}$ & $\mathbf{L} \mathbf{2} / \mathbf{m}$ & $\begin{array}{c}\text { charging } \\
\text { height } \\
\boldsymbol{h 1 / m}\end{array}$ & $\begin{array}{c}\text { stemming } \\
\text { height } \\
\boldsymbol{h} \mathbf{2} / \mathbf{m}\end{array}$ & $\begin{array}{c}\text { slope } \\
\text { ratio }\end{array}$ \\
\hline 15 & 250 & 19 & $3 \mathrm{a}$ & $3 \mathrm{~b}$ & $3 \mathrm{~b}+2$ & 11.5 & 6 & $15 / 1$ \\
\hline
\end{tabular}




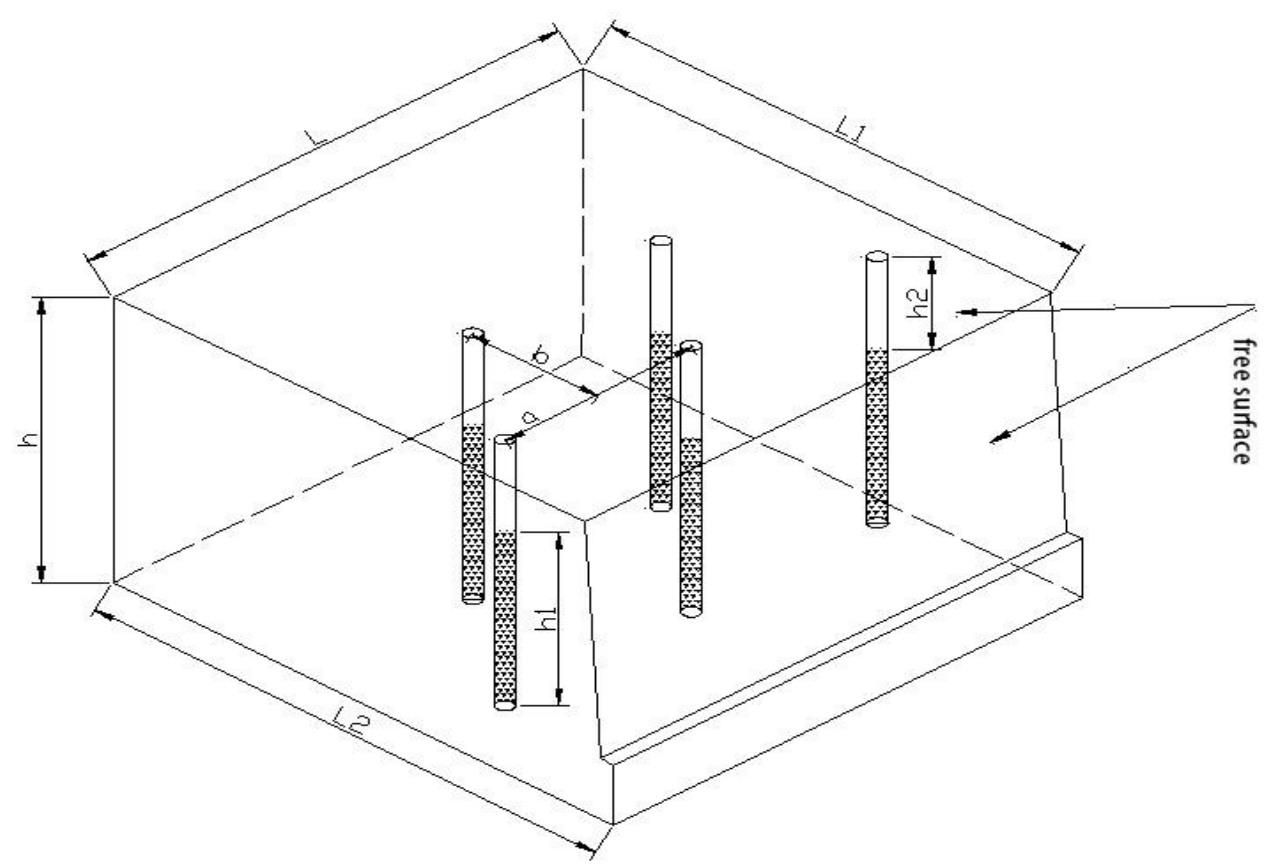

Figure 1. Calculation Model

\subsection{Materials Model}

When explosive is blasting in rocks, complex stress changes will appear in the rock mass nears blast hole with obvious effect of strain rate [12].Therefore, the simulating rocks material selection plastic strain for kinematic hardening materials model *MAT_PLASTIC_KINEMATIC and the physical and mechanics parameters of rocks refers to Table 5. Rock emulsion explosive is used. The material model of explosive is high-performance explosive model MAT_HIGH_EXPLOSIVE_BURN. Emulsion explosive and its equation parameters [10] under JWL status are showed in Table 6.

Table 5. The Physical and Mechanics Parameters of Rock

\begin{tabular}{|c|c|c|c|c|c|c|c|}
\hline Rock & $\begin{array}{c}\text { Density } \\
p / 10^{3} \\
\mathrm{~kg} / \mathrm{m}^{3}\end{array}$ & $\begin{array}{c}\text { Elastic } \\
\text { modulus } \\
/ 10^{10} \mathrm{~Pa}\end{array}$ & $\begin{array}{c}\text { Poisson's } \\
\text { Ratio } \\
/ \lambda\end{array}$ & $\begin{array}{c}\text { Staticcom } \\
\text { pressive } \\
\text { strength } \\
/ \text { Mpa }\end{array}$ & $\begin{array}{c}\text { Dynamic } \\
\text { compressi } \\
\text { ve } \\
\text { strength } \\
\text { /Mpa }\end{array}$ & $\begin{array}{c}\text { Statictensile } \\
\text { strength } \\
\text { /Mpa }\end{array}$ & $\begin{array}{c}\text { Dynamic } \\
\text { tensile } \\
\text { strength } \\
\text { /Mpa }\end{array}$ \\
\hline schist & 2.6 & 6.0 & 0.25 & 23.6 & 196.5 & 2.36 & 23.6 \\
\hline
\end{tabular}

Table 6. The Parameters of Emulsion Explosive

\begin{tabular}{|c|c|c|c|c|c|c|c|c|c|}
\hline $\begin{array}{c}\text { Density } \\
\left(\mathbf{k g} / \mathbf{m}^{\mathbf{3}}\right)\end{array}$ & $\begin{array}{c}\text { Detonation } \\
\text { velocity } \\
(\mathbf{m} / \mathbf{s})\end{array}$ & $\boldsymbol{P}_{\boldsymbol{C}-\boldsymbol{J}}(\mathbf{G p a})$ & $\boldsymbol{V}_{\boldsymbol{0}}$ & $\boldsymbol{A}(\mathbf{G p a})$ & $\boldsymbol{B}(\mathbf{G p a})$ & $\boldsymbol{R}_{\boldsymbol{I}}$ & $\boldsymbol{R}_{\boldsymbol{2}}$ & $\boldsymbol{W}$ & $\boldsymbol{E}_{\boldsymbol{0}}(\mathbf{G p a})$ \\
\hline $1.2 \times 10^{3}$ & $4.8 \times 10^{3}$ & 5.15 & 1.0 & 293.9 & 21.73 & 6.37 & 2.15 & 0.21 & 3.14 \\
\hline
\end{tabular}

\subsection{Calculations Results and Analysis}

(1) Analysis on propagation process of effective stress

The target of this simulation is to research and analyze the fracture situation of rocks after explosion. Therefore, taking model 1-1 as analysis target, propagation distribution situation of stress waves at different moments is showed as Figure 2. 
International Journal of $u-$ and e- Service, Science and Technology

Vol. 9, No. 12 (2016)

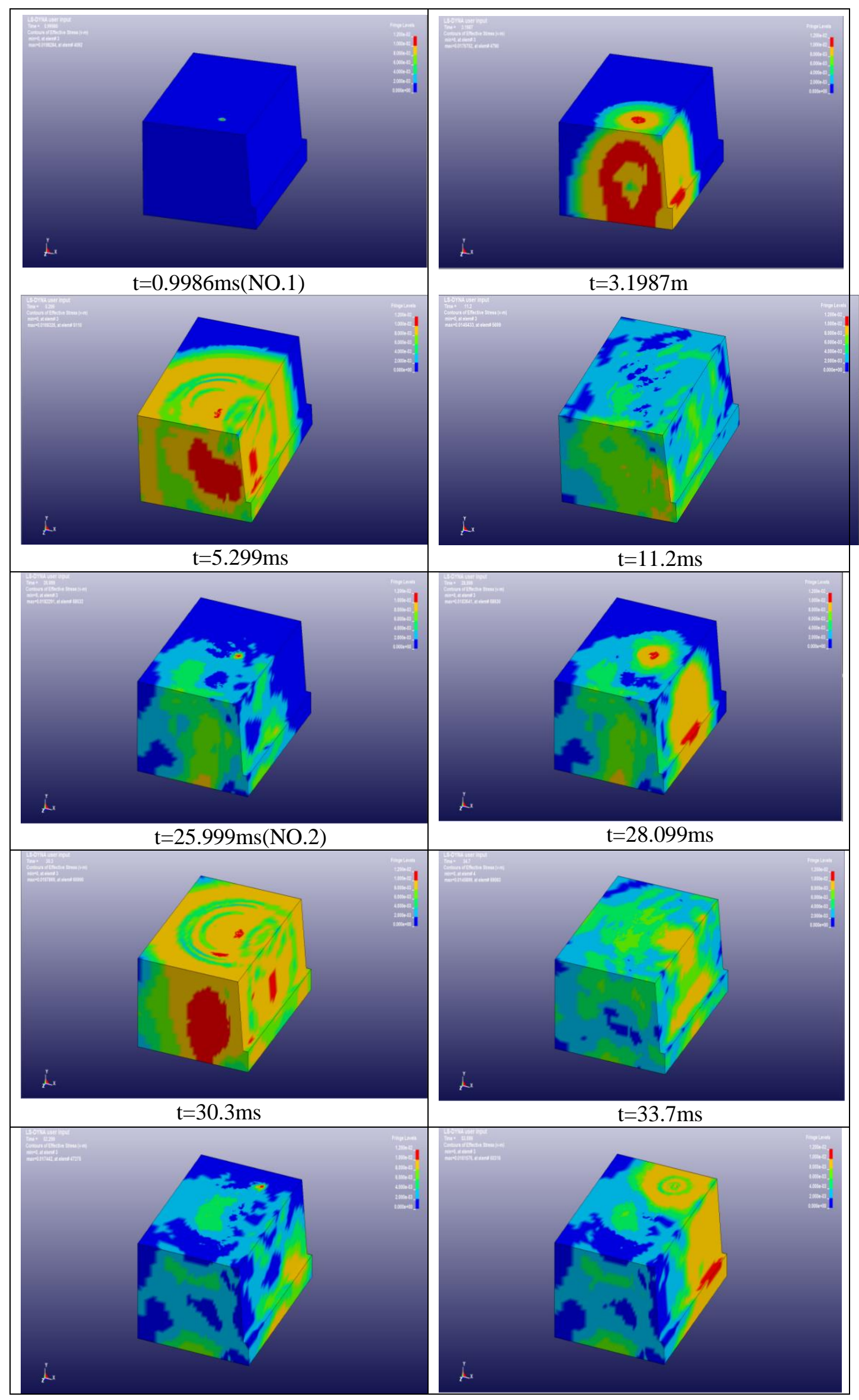




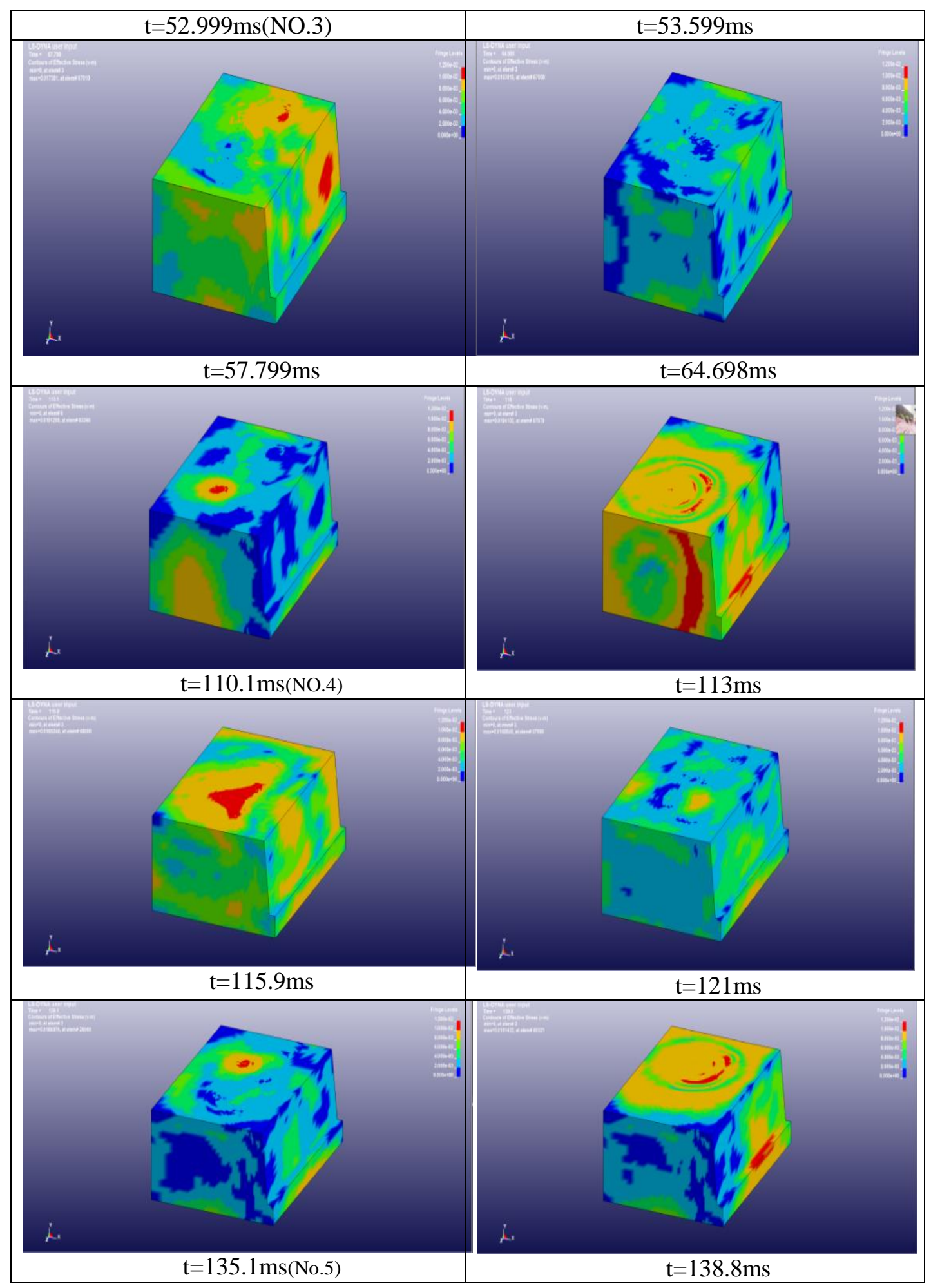




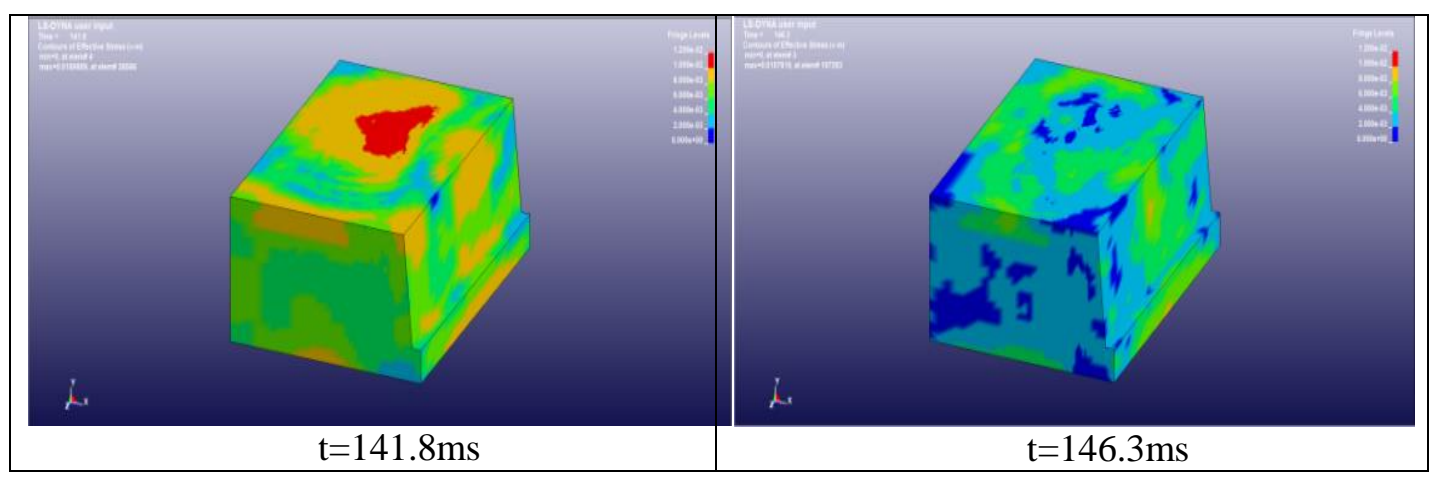

Figure 2. Stress Waves at Different Moments

It can be seen from Figure 2, that the stress waves after initiation is propagated as circular outwards. At this time, the stress is pressure stress. When stress waves reach faces and formed reflected wave on free faces, the stress is pulling stress. Where is redder, where stress is bigger. It can be seen from the figure that the delay time interval between holes is $25 \mathrm{~ms}$, and between rows is $110 \mathrm{~ms}$. The blasting of each blast hole is dependent, and stress waves are not overlaid in big scale.

(2) Analysis on stress of discrete cell

In order to judge whether the rock of ore body will be destroyed under different hole pattern parameters. 6 discrete cells are selected in the model. The stress of discrete cells between blast holes is analyzed to express the destroying extent of the rocks in that cell. If the stress peak value reaches or exceeds $23.6 \mathrm{Mpa}$ of the dynamic tensile strength of rocks, it means that the rock $\mathrm{i}$ that cell may be destroyed. Otherwise, the rocks cannot be destroyed. Time-step recording spot of stress in discrete cell between blast holes is showed as Figure 3.The time-step curves of the stress in discrete cell of model 1-1 is listed as Figure 4.The stress peaks in discrete cells of 6 different schemes refers to Table 7.

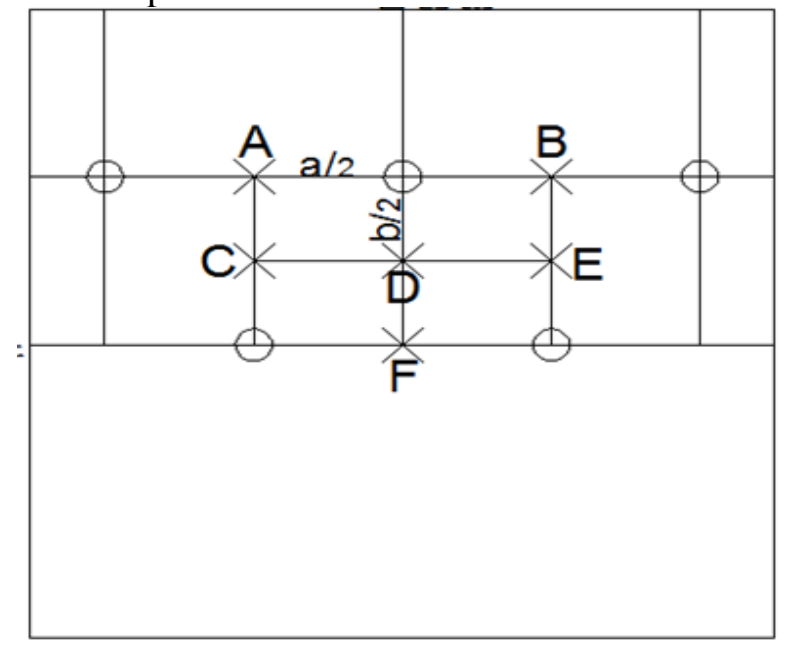

Figure 3. Time-step Recording Spot of Stress 


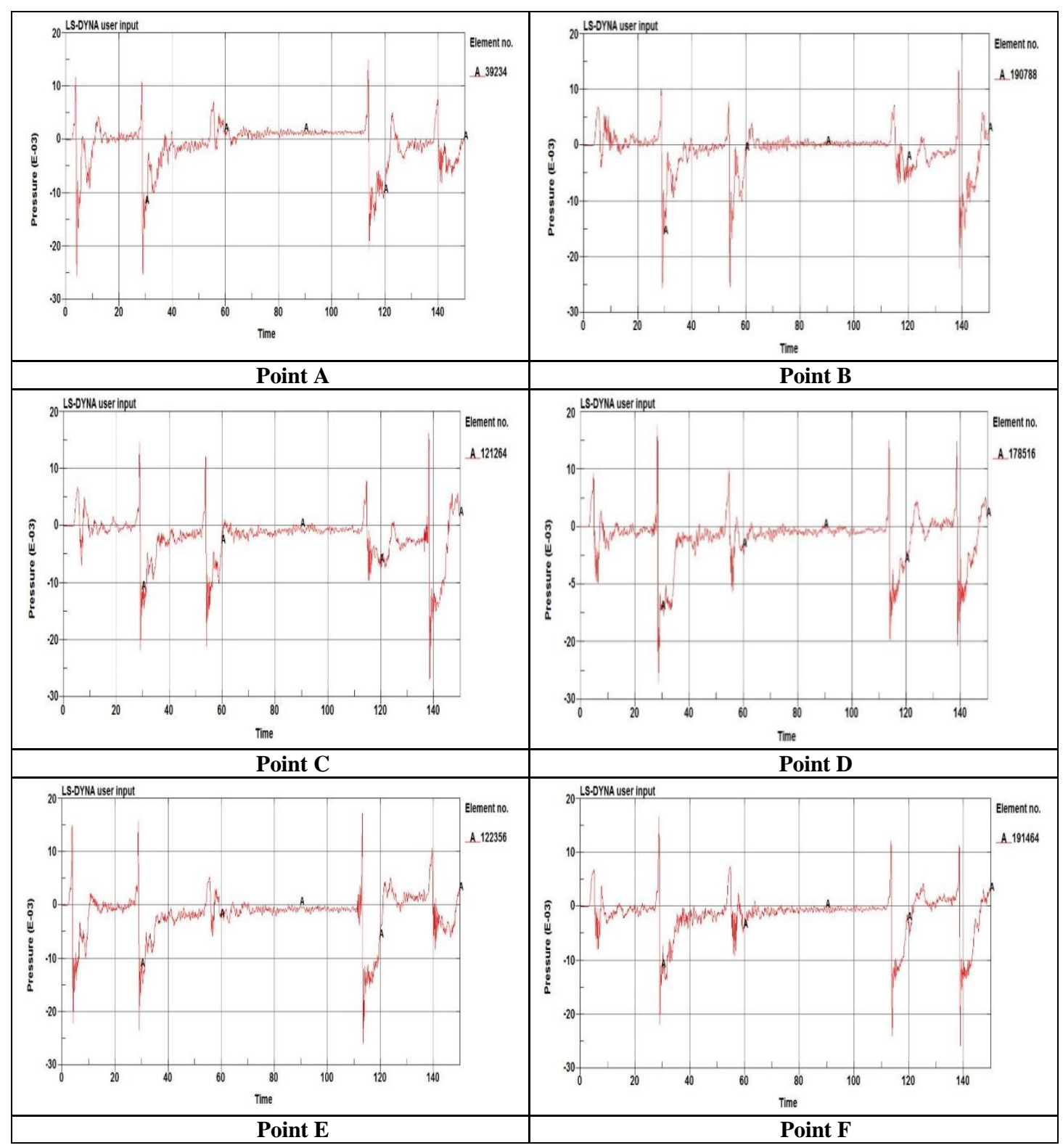

Figure 4. The Time-Step Curves of The Stress in Discrete Cell of Model 1-1

Table 7. The Stress Peaks in Discrete Cells

\begin{tabular}{|c|c|c|c|c|c|c|c|c|c|c|}
\hline \multirow[b]{2}{*}{$\begin{array}{c}\text { Model } \\
\text { numb } \\
\text { er }\end{array}$} & \multirow[b]{2}{*}{$\begin{array}{c}\text { Bench } \\
\text { height } \\
/ \mathrm{m}\end{array}$} & \multirow[b]{2}{*}{$\begin{array}{l}\text { Hole } \\
\text { dept } \\
\text { h/m }\end{array}$} & \multirow[b]{2}{*}{$\begin{array}{c}\text { Holes } \\
\text { pacing } \\
\text { /m }\end{array}$} & \multirow[b]{2}{*}{$\begin{array}{c}\text { Rowspa } \\
\text { cing } \\
\text { /m }\end{array}$} & \multicolumn{6}{|c|}{ The max of effective stress/MPa } \\
\hline & & & & & $\begin{array}{c}\text { Poin } \\
\text { A }\end{array}$ & $\begin{array}{c}\text { Point } \\
\text { B }\end{array}$ & $\begin{array}{c}\text { Point } \\
\text { C }\end{array}$ & $\begin{array}{c}\text { Point } \\
\text { D }\end{array}$ & $\begin{array}{c}\text { Point } \\
\text { E }\end{array}$ & $\begin{array}{c}\text { Point } \\
\text { F }\end{array}$ \\
\hline \multirow{2}{*}{$1-1$} & \multirow{6}{*}{5} & \multirow{6}{*}{17.5} & \multirow{2}{*}{15} & \multirow{2}{*}{10} & 26.0 & 26.5 & 21.7 & 22.8 & 21.6 & 26.2 \\
\hline & & & & & 279 & 965 & 134 & 767 & 253 & 930 \\
\hline \multirow{2}{*}{$1-2$} & & & \multirow{2}{*}{15} & \multirow{2}{*}{9} & 27.8 & 27.6 & 23.3 & 24.1 & 23.4 & 27.5 \\
\hline & & & & & 337 & 969 & 629 & 998 & 711 & 616 \\
\hline \multirow{2}{*}{$1-3$} & & & \multirow{2}{*}{16} & \multirow{2}{*}{9} & 25.1 & 24.8 & 24.4 & 25.9 & 24.6 & 25.0 \\
\hline & & & & & 893 & 820 & 657 & 190 & 063 & 165 \\
\hline
\end{tabular}




\begin{tabular}{|c|c|c|c|c|c|c|c|c|}
\hline $1-4$ & 17 & 8 & $\begin{array}{l}23.5 \\
895\end{array}$ & $\begin{array}{c}24.1 \\
594\end{array}$ & $\begin{array}{l}25.0 \\
845\end{array}$ & $\begin{array}{c}25.6 \\
898\end{array}$ & $\begin{array}{l}25.2 \\
686\end{array}$ & $\begin{array}{l}24.9 \\
365\end{array}$ \\
\hline $1-5$ & 18 & 8 & $\begin{array}{c}20.8 \\
599\end{array}$ & $\begin{array}{l}19.9 \\
316\end{array}$ & $\begin{array}{l}24.2 \\
297\end{array}$ & $\begin{array}{c}24.9 \\
560\end{array}$ & $\begin{array}{l}23.9 \\
255\end{array}$ & $\begin{array}{c}20.3 \\
468\end{array}$ \\
\hline $1-6$ & 19 & 7 & $\begin{array}{l}20.1 \\
696\end{array}$ & $\begin{array}{c}20.0 \\
624\end{array}$ & $\begin{array}{c}26.4 \\
687\end{array}$ & $\begin{array}{c}26.0 \\
019\end{array}$ & $\begin{array}{l}25.2 \\
989\end{array}$ & $\begin{array}{l}20.1 \\
433\end{array}$ \\
\hline
\end{tabular}

The 6 groups of blasting design schemes is comparatively analyzed according to the stress time step curves in figure 4 and the maximum stress in discrete cells of each group in Table 7, and the result is as follow:

(1) If the row spacing of blast holes is $15 \times 10$ and the stress between two hole is big, the effective stress at A, B, and F points of stress cell between two holes is bigger than the dynamic tensile strength, it means that the rock in this area can be destroyed. If the effective stress at C, D, and E points of stress cell between rows of the model is lower than the dynamic tensile strength, it means the rocks in this area can't be destroyed or boulder may occur in the explosion.

(2) If the row spacing of blast holes is $15 \times 9$ or $16 \times 9$ or $17 \times 8$, the effective stress at $A$, $\mathrm{B}$, and $\mathrm{F}$ points of stress cell between holes of the model is bigger than the dynamic tensile strength of rocks, it means the rock in this area of the model can be destroyed. If the effective stress at C, D, and E points of stress cell between rows of the model is a little bigger than the dynamic tensile strength of rocks, it means the rocks in this area can be destroyed.

(3) If the row spacing of blast holes is $18 \times 8$ or $19 \times 7$, the effective stress at $\mathrm{A}, \mathrm{B}$, and $\mathrm{F}$ points of stress cell between holes of the model is less than the dynamic tensile strength of rocks, it means the rock in this area of the model cannot be destroyed. If the effective stress at $\mathrm{C}, \mathrm{D}$, and $\mathrm{E}$ points of stress cell between rows of the model is a bigger than the dynamic tensile strength of rocks, it means the rocks in this area can be destroyed.

And above all, $15 \times 9,16 \times 9,17 \times 8$ three design schemes are selected for site explosion test according to comparison between the effective stress in discrete cell of each scheme explosion simulation and the dynamic tensile strength of rocks.

\section{Engineering Test}

\subsection{Blasting Test Scheme}

(1)Site test parameters

The results of numerical simulation shows that the simulated explosion in $15 \times 9,16 \times 9$, $17 \times 8$ groups of hole pattern parameters has best effects. In order to find the best hole pattern parameters, according to the blasting parameters of site test confirmed before, 1230 platform in Manjiazhai stope, which is accords with the nature of simulated rocks, is selected for site blasting test. The detailed test parameters refer to Table 8 .

Table 8. The Detailed Test Parameters

\begin{tabular}{|c|c|c|c|c|c|c|c|c|c|c|c|c|}
\hline \multirow{2}{*}{$\begin{array}{c}\text { Nu } \\
\text { mb } \\
\text { er }\end{array}$} & \multirow{2}{*}{$\begin{array}{c}\text { Benc } \\
\text { h } \\
\text { heig } \\
\text { ht } \\
\text { /m }\end{array}$} & \multirow{2}{*}{$\begin{array}{c}\text { Bott } \\
\text { om } \\
\text { burd } \\
\text { en } \\
\text { /m }\end{array}$} & \multirow{2}{*}{$\begin{array}{c}\text { Hole } \\
\text { spac } \\
\text { ing } \\
/ \mathrm{m}\end{array}$} & \multirow{2}{*}{$\begin{array}{c}\text { Row } \\
\text { spac } \\
\text { ing } \\
/ \mathrm{m}\end{array}$} & \multicolumn{2}{|c|}{$\begin{array}{l}\text { Delayed } \\
\text { time /ms }\end{array}$} & \multirow{2}{*}{$\begin{array}{c}\text { Single } \\
\text {-hole } \\
\text { burde } \\
\text { n } \\
\text { area } \\
/ \mathbf{m}^{2}\end{array}$} & \multirow{2}{*}{$\begin{array}{c}\text { Hol } \\
\text { e } \\
\text { dep } \\
\text { th } \\
/ \mathrm{m}\end{array}$} & \multirow{2}{*}{$\begin{array}{c}\text { Extr } \\
\text { a- } \\
\text { dept } \\
\text { h } \\
/ \mathbf{m}\end{array}$} & \multirow{2}{*}{$\begin{array}{l}\text { Stem } \\
\text { ming } \\
\text { heig } \\
\text { ht/m }\end{array}$} & \multirow{2}{*}{$\begin{array}{c}\text { The } \\
\text { charg } \\
\text { e } \\
\text { of a bl } \\
\text { ast } \\
\text { hole } \\
/ \mathbf{k g}\end{array}$} & \multirow{2}{*}{$\begin{array}{c}\text { The } \\
\text { specif } \\
\text { ic } \\
\text { charg } \\
\text { e } \\
/(\mathbf{k g} / \\
\left.\mathbf{m}^{3}\right)\end{array}$} \\
\hline & & & & & $\begin{array}{c}\text { hole } \\
\mathbf{s}\end{array}$ & $\begin{array}{c}\text { row } \\
\mathbf{s}\end{array}$ & & & & & & \\
\hline $1-1$ & 15.0 & 9.3 & 15.1 & 9.0 & 25 & 110 & 135.9 & 17.8 & 3.0 & 6.4 & 654 & 0.327 \\
\hline
\end{tabular}




\begin{tabular}{|l|l|l|l|l|l|l|l|l|l|l|l|l|}
\hline $\mathbf{1 - 2}$ & 14.8 & 9.3 & 15.0 & 9.0 & 25 & 110 & 135 & 17.5 & 2.7 & 5.8 & 648 & 0.324 \\
\hline $\mathbf{1 - 3}$ & 15.0 & 9.4 & 14.8 & 9.1 & 25 & 110 & $\begin{array}{c}134.6 \\
8\end{array}$ & 17.5 & 2.5 & 7.0 & 648 & 0.320 \\
\hline $\mathbf{1 - 4}$ & 14.9 & 9.5 & 15.0 & 9.0 & 25 & 110 & 135 & 17.8 & 2.9 & 6.0 & 654 & 0.325 \\
\hline $\mathbf{1 - 5}$ & 14.8 & 9.6 & 15.2 & 8.9 & 25 & 110 & $\begin{array}{c}135.2 \\
8\end{array}$ & 17.6 & 3.1 & 6.5 & 648 & 0.324 \\
\hline $\mathbf{2 - 1}$ & 15.1 & 9.5 & 16.1 & 9.2 & 25 & 110 & $\begin{array}{c}148.1 \\
2\end{array}$ & 17.9 & 2.3 & 6.6 & 696 & 0.320 \\
\hline $\mathbf{2 - 2}$ & 14.9 & 9.4 & 16.0 & 9.0 & 25 & 110 & 144 & 17.8 & 2.9 & 5.6 & 702 & 0.327 \\
\hline $\mathbf{2 - 3}$ & 15.0 & 9.4 & 16.0 & 9.0 & 25 & 110 & 144 & 17.5 & 2.5 & 6.8 & 690 & 0.319 \\
\hline $\mathbf{2 - 4}$ & 15.1 & 9.4 & 15.8 & 9.1 & 25 & 110 & $\begin{array}{c}143.7 \\
8\end{array}$ & 17.4 & 2.3 & 5.4 & 696 & 0.320 \\
\hline $\mathbf{2 - 5}$ & 14.8 & 9.5 & 16.1 & 9.0 & 25 & 110 & 144.9 & 17.8 & 3 & 6.0 & 690 & 0.324 \\
\hline $\mathbf{3 - 1}$ & 15.4 & 9.4 & 17.1 & 7.8 & 25 & 110 & $\begin{array}{c}133.3 \\
8\end{array}$ & 17.3 & 2.9 & 6.0 & 660 & 0.315 \\
\hline $\mathbf{3 - 2}$ & 14.6 & 9.5 & 17.2 & 8.0 & 25 & 110 & 137.6 & 17.4 & 2.8 & 6.0 & 666 & 0.335 \\
\hline $\mathbf{3 - 3}$ & 15.1 & 9.3 & 17.0 & 8.0 & 25 & 110 & 136 & 17.9 & 2.8 & 6.4 & 666 & 0.324 \\
\hline $\mathbf{3 - 4}$ & 14.9 & 9.4 & 16.9 & 8.1 & 25 & 110 & $\begin{array}{c}136.8 \\
9\end{array}$ & 17.3 & 2.4 & 6.0 & 648 & 0.320 \\
\hline $\mathbf{3 - 5}$ & 15.2 & 9.5 & 17.0 & 8.0 & 25 & 110 & 136 & 17.5 & 2.3 & 6.0 & 660 & 0.319 \\
\hline
\end{tabular}

(2)Initiating network of site test

A slash initiating network is selected in this site blasting experiment with millisecond time between holes $T_{1}=25 \mathrm{~ms}$, the millisecond time between rows $T_{2}=110 \mathrm{~ms}$. Connect the first blast hole in the back row and the second blast hole of front row with a millisecond detonator between rows and form a slash initiating network as showed in Figure 5. 


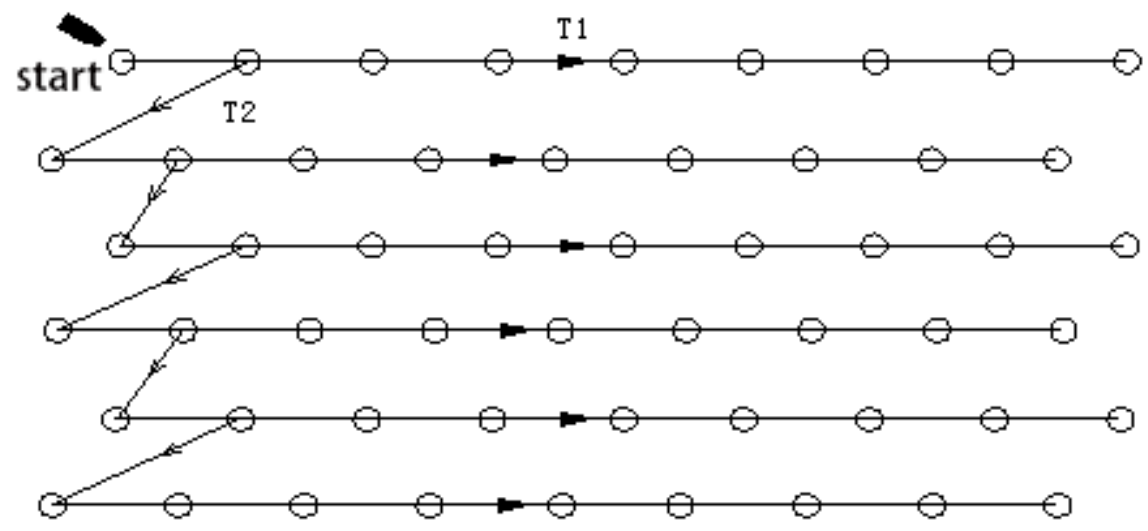

Figure 5. Initiating Network

\subsection{Blasting Effect Analysis}

The elements, for judging whether the bench blasting is good or not, include explosive consumption, the loosening degree of muck pile, boulder yield and shovel mucking efficiency and etc., This paper insists the principle of easy collecting and significant function analyzes and contrasts boulder yield, shovel mucking efficiency and composite economic results.

(1) Boulder yield analysis

Table 9. The Boulder Yield

\begin{tabular}{|c|c|c|c|c|c|c|c|}
\hline Number & $\begin{array}{c}\text { Hole } \\
\text { spacing/ } \\
\mathbf{m}\end{array}$ & $\begin{array}{c}\text { Row } \\
\text { spacing/ } \\
\mathbf{m}\end{array}$ & $\begin{array}{c}\text { The } \\
\text { total } \\
\text { volume } \\
\mathbf{/ m}^{\mathbf{3}}\end{array}$ & Quantity & $\begin{array}{c}\text { Volume } \\
\mathbf{/ m}^{\mathbf{3}}\end{array}$ & $\begin{array}{c}\text { The } \\
\text { maximum } \\
\text { size /cm }\end{array}$ & $\begin{array}{c}\text { Boulder } \\
\text { yield/ \% }\end{array}$ \\
\hline $\mathbf{1 - 1}$ & 15.1 & 9.0 & 30577.5 & 18 & 3030 & 165 & $9.91 \%$ \\
\hline $\mathbf{1 - 2}$ & 15.0 & 9.0 & 29970.0 & 16 & 2562 & 159 & $8.55 \%$ \\
\hline $\mathbf{1 - 3}$ & 14.8 & 9.1 & 36363.6 & 26 & 3629 & 142 & $9.98 \%$ \\
\hline $\mathbf{1 - 4}$ & 15.0 & 9.0 & 36207.0 & 20 & 3081 & 153 & $8.51 \%$ \\
\hline $\mathbf{1 - 5}$ & 15.2 & 8.9 & 30032.2 & 15 & 3117 & 374 & $10.38 \%$ \\
\hline $\mathbf{2 - 1}$ & 16.1 & 9.2 & 33549.2 & 13 & 2285 & 180 & $6.81 \%$ \\
\hline $\mathbf{2 - 2}$ & 16.0 & 9.0 & 32184.0 & 13 & 2253 & 169 & $7.00 \%$ \\
\hline $\mathbf{2 - 3}$ & 16.0 & 9.0 & 25920 & 19 & 2250 & 317 & $8.68 \%$ \\
\hline $\mathbf{2 - 4}$ & 15.8 & 9.1 & 39079.4 & 23 & 3165 & 135 & $8.10 \%$ \\
\hline $\mathbf{2 - 5}$ & 16.1 & 9.0 & 25734.2 & 12 & 1858 & 159 & $7.22 \%$ \\
\hline $\mathbf{3 - 1}$ & 17.1 & 7.8 & 30810.8 & 18 & 2785 & 157 & $9.04 \%$ \\
\hline $\mathbf{3 - 2}$ & 17.2 & 8.0 & 24107.5 & 12 & 2153 & 184 & $8.93 \%$ \\
\hline $\mathbf{3 - 3}$ & 17.0 & 8.0 & 30804.0 & 18 & 1993 & 110 & $6.47 \%$ \\
\hline $\mathbf{3 - 4}$ & 16.9 & 8.1 & 24475.9 & 13 & 2102 & 159 & $8.59 \%$ \\
\hline $\mathbf{3 - 5}$ & 17.0 & 8.0 & 24806.4 & 16 & 1930 & 123 & $7.78 \%$ \\
\hline
\end{tabular}

From the calculation of statistical Table 9, of boulder yield, when the holes and rows spacing are $15 \times 9$, the average boulder yield is $9.466 \%$; When the holes and rows spacing are $16 \times 9$, the average boulder yield is $7.562 \%$; When the holes and rows spacing are $17 \times$ 8 , the average boulder yield is $8.162 \%$; From the comparison of the three groups of holes 
and rows spacing, the average boulder yield when the holes and rows spacing are $16 \times 9$ is $1.904 \%$ lower than those are $15 \times 9$, and $1.079 \%$ lower than those are $17 \times 8$.

(2) Analyze on shovel mucking efficiency

Table 10. The Shovel Mucking Efficiency

\begin{tabular}{|c|c|c|c|c|}
\hline Number & $\begin{array}{c}\text { Hole spacing } \\
\text { /m }\end{array}$ & $\begin{array}{c}\text { Row spacing } \\
\mathbf{/ m}\end{array}$ & $\begin{array}{c}\text { Transportation } \\
\text { vehicle }\end{array}$ & $\begin{array}{c}\text { Efficiency } \\
/(\mathbf{t} / \mathbf{h})\end{array}$ \\
\hline $\mathbf{1 - 1}$ & 15.1 & 9.0 & 129 & 1451.25 \\
\hline $\mathbf{1 - 2}$ & 15.0 & 9.0 & 135 & 1518.75 \\
\hline $\mathbf{1 - 3}$ & 14.8 & 9.1 & 120 & 1350 \\
\hline $\mathbf{1 - 4}$ & 15.0 & 9.0 & 123 & 1383.75 \\
\hline $\mathbf{1 - 5}$ & 15.2 & 8.9 & 110 & 1237.5 \\
\hline $\mathbf{2 - 1}$ & 16.1 & 9.2 & 130 & 1462.5 \\
\hline $\mathbf{2 - 2}$ & 16.0 & 9.0 & 127 & 1428.75 \\
\hline $\mathbf{2 - 3}$ & 16.0 & 9.0 & 118 & 1327.5 \\
\hline $\mathbf{2 - 4}$ & 15.8 & 9.1 & 131 & 1473.75 \\
\hline $\mathbf{2 - 5}$ & 16.1 & 9.0 & 139 & 1563.75 \\
\hline $\mathbf{3 - 1}$ & 17.1 & 7.8 & 120 & 1350 \\
\hline $\mathbf{3 - 2}$ & 17.2 & 8.0 & 126 & 1417.5 \\
\hline $\mathbf{3 - 3}$ & 17.0 & 8.0 & 134 & 1507.5 \\
\hline $\mathbf{3 - 4}$ & 14.9 & 16.9 & 115 & 1293.75 \\
\hline $\mathbf{3 - 5}$ & 15.2 & 17.0 & 109 & 1226.25 \\
\hline
\end{tabular}

From Table 10, when the holes and rows spacing are $15 \times 9$, the shovel mucking efficiency is $1388.25 \mathrm{t} / \mathrm{h}$; when the holes and rows spacing are $16 \times 9$, the shovel mucking efficiency is $1451.25 \mathrm{t} / \mathrm{h}$; when the holes and rows spacing are $17 \times 8$, the shovel mucking efficiency is $1359.0 \mathrm{t} / \mathrm{h}$; From the comparisons, the shovel mucking efficiency when the holes and rows spacing are $16 \times 9$ is higher than the other two conditions.

(3)Economic profit analysis

The cost of $16 \times 9$ holes and rows spacing is lower than those of $17 \times 8$ and $15 \times 9$, and the linear meter volume is bigger, which improves the charging efficiency, reduces the times of moving drilling rig and stability and improves man-hour utilization rate.

By synthesizing the overall evaluation indexes of blasting effect, the hole pattern parameters of scheme $16 \times 9$ is better meet with the requirements of blasting production in Manjiazhai stope of Hualian Zinc and Indium Stock company. The blasting effect is showed as figure 6 .

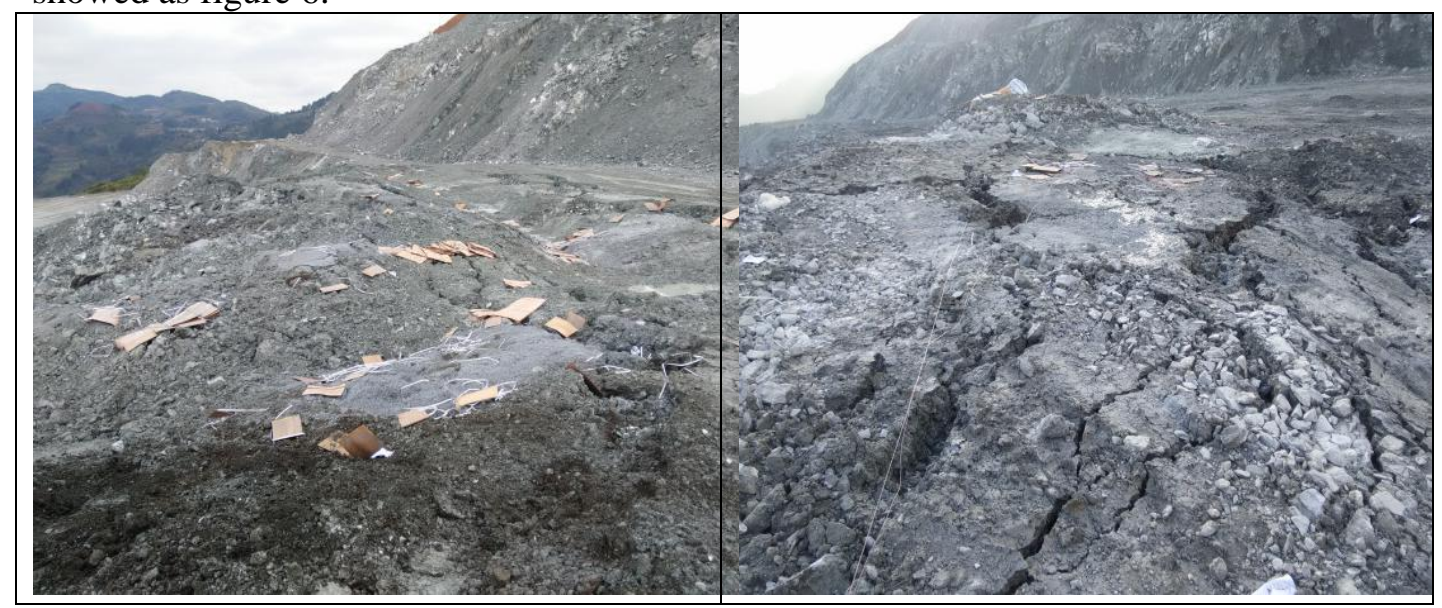




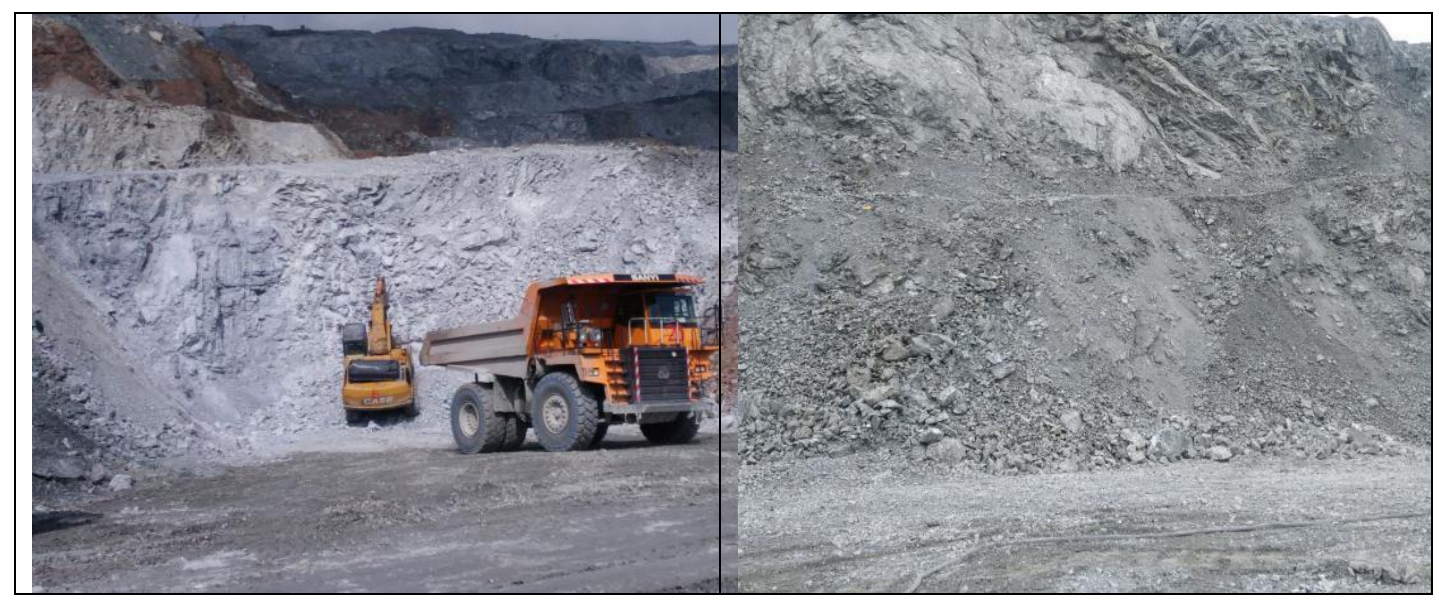

Figure 6. The Blasting Effect

\section{Conclusions}

(1) By analyzing the blasting mechanism of wide hole spacing and small resistance lines and combining with the actual production situation, 6 different parameters of blasting hole pattern optimized.

(2) By numerical simulation of the designed blasting hole pattern parameters with finite element software ANSYS/LS-DYNA, and analysis on the destroying degree on rocks expressed by the stress in discrete cells between blast holes, three groups of parameters, in which the holes and rows spacing are $15 \times 9,16 \times 9,17 \times 8$ suitable for deephole bench loosening blasting.

(3) Using the results got from numerical simulation in site test, and statistical analysis on blasting effect shows that the average boulder yield when the holes and rows spacing are $16 \times 9$ is $1.904 \%$ lower than those are $15 \times 9$, and $1.079 \%$ lower than those are $17 \times 8$. And its shovel mucking efficiency and composite economic results is better than the other two groups. Thus the hole pattern parameters when the holes and rows spacing are $16 \times 9$ is the best scheme of blasting parameter, solving the problems in mines blasting construction and providing guidance for successive engineering.

\section{References}

[1] S. C. Zhang, R. J. Gou and Z. Y. Ma, "Parameters Optimized Design of Open Deep-Hole Bench Surface Blasting", Journal of North University of China (Natural Science Editon). vol. 37, no. 2, (2016), pp. 166-171.

[2] X. G. Wang, Editor, "Blasting Design and Construction”, Metallurgical Industry Press, Beijing, (2011).

[3] T. Hu and M. J. Wang, "Blasting Parameters Optimization and Fragmentation Prediction in The Open-Pit Mine”, Opencast Mining Technology. no. 2, (2015), pp. 39-42.

[4] S. Xu, J. Y. Peng and Y. H. Li, "Blasting Parameter Optimization of Medium-Depth Hole Caving for Steeply Inclined Thin Veins”, Explosion and Shock Waves, vol. 35, no. 5, (2015), pp. 682-688.

[5] J. H. Yang, W. B. Lu and M. Chen, "An Equivalent Simulation Method for Blasting Vibration of Surrounding Rock", Explosion and Shock Waves, vol. 32, (2012), pp. 157-163.

[6] H. Wang, Q. Zong and Y. Zhao. "Numerical Analysis and Application of Large Diameter Cavity Parallel Cut Blasting Stress Field in Vertical Shaft", Chinese Journal of Rock Mechanics and Engineering, vol. 34, supp.1, (2015), pp. 3223-3229.

[7] C. Li, W. Qi, Y. Li, and J. Wei, "Application of Long Hole Distance-Short Array Distance Blasting in Daheishan Molybdenum Mine", Gold, vol.32, no.7, (2011), pp.36-39.

[8] C. S, Zheng, J. K. Zhuang, and Z. J. Li, "Wide Hole Spacing Small Burden Technology Applied in Deep Hole Blasting", Mining Engineering, vol.8, no. 3, (2010), pp.40-42.

[9] Q. Zong and C. P. Wang, "Investigation and Application of Large Spacing Loose Blasting in Rock", Blasting, vol.18, no.1, (2001), pp. 1-4.

[10] S. X. Cao, X. Y. Qiu and X. Z. Shi, "Research on The Parameters Optlmization of Large Diameter Longhole Blasting”, Nonferrous Metals Engineering, vol. 5, no. B05, (2015), pp. 160-164. 
[11] E. H. Su, "Discussion on Optimization and Construction Technology of Large Diameter Deep Hole Blasting in Open Pit Mine", Opencast Mining Technology, no.10, (2013), pp.15-17.

[12] X. B. Li and D. S. Du, Editor, "Rock Impact Dynamics", Central South University of Technology Press, Hunan, (1994). 
International Journal of $u-$ and e- Service, Science and Technology Vol. 9, No. 12 (2016) 